\title{
Perceived effect of motivational strategies of promotion and work environment on the job performance of library personnel of universities in Benue State, Nigeria
}

\author{
Margaret Mngusuur Ubagu, $C L N$ \\ Assistant Librarian \\ University Library and Information Services \\ Benue State University, Makurdi \\ E-mail: margaretubagu@gmail.com \\ Cell: +2348081227316 \\ Uganneya Solomon Achia, $P h D$ \\ University Librarian \\ Federal University of Agriculture, Makurdi \\ E-mail: solomonachia@gmail.com \\ Joseph Ahemba Gbuushi, CLN \\ Assistant Librarian \\ University Library and Information Services \\ Benue State University, Makurdi \\ E-mail: josephgbuushi@gmail.com \\ Cell: +2348160640839
}

\begin{abstract}
The study was conducted to determine the perceived effect of motivational strategies of promotion and work environment on the job performance of library personnel of universities in Benue State. Two objectives were stated to find out the perceived effect of timely promotion and good work environment of library personnel of universities in Benue State. Two research questions drawn and two hypotheses formulated in line with the stated objectives. Survey research design was adopted. The study population was 223 library personnel from Federal University of Agriculture, Makurdi, Benue State University, Makurdi and University of Mkar, Mkar, both in Nigeria. The entire population was used as sample for the study. Mean values were used to answer research questions while one way Analysis of Variance (ANOVA) was used to the test hypotheses at 0.05 level of significance. The study found that timely promotion and good work environment have significant difference on job performance of library personnel of universities in Benue State. The study recommended therefore, that work environment of the university libraries in Benue State should be made conducive by the provision of adequately equipped and well ventilated space, ICT gadgets such as computers, internet connectivity, for enhanced job performance.
\end{abstract}

Keywords: Motivation strategies, Job performance, University library, Personnel, Promotion, Work environment, Benue State, Nigeria

\section{Introduction}

The objective of attaining productivity in an organization can only be achieved if the overall job performance of the entire staff is enhanced. Studies have shown that variables such as job motivation and satisfaction are germane to improving the degree of job performance of staff in any organization which in turn determines the level of productivity (Katamba \& Abdusalam, 2014). According to Kendra (2019), motivation is regarded as the use of 
Margaret Mngusnur Ubagu, Uganneya Solomon Achia and Joseph Ahemba Gbuushi: Perceived effect of motivational strategies of promotion and work environment on the job performance of library personnel of universities in Benue State, Nigeria

incentives to person from whom activity is needed or required. Job satisfaction is linked to motivation and thus satisfaction leads to better performance. For workers to be effectively directed and to perform better in their roles, personnel motivation must be given adequate attention that is timely promotion of workers as well as conducive work environment.

Motivation plays a big role in job performance of workers. The Library personnel are not left out. Workers who are motivated with good salary package, conducive work environment, regular promotion, good communication climate, staff training and development among others are likely to exhibit high level of job performance. This corroborates (Tella, Ayeni and Popoola 2007) who states that work motivation is an important factor in predicting the work performance of employees in both private and public sector organizations.

The library personnel may give the necessary support and life to all the material resources to provide useful service to the library users if they are sufficiently motivated. The library is the central point of the whole university system where-in one could find the various functions performed and services rendered by library personnel. The Library personnel according to Uganneya and Agoh (2013) constitute an important component of a library that translates all the policies of the library into action. Hence, the caliber of the staff in a library determines the quality of services rendered in a library. Librarianship like any other profession is a skilled profession, which requires high standard of profession training.

Observation show that most times users of library resources complain of library personnels' failure to attend to their information needs properly. This has been attributed to lack of motivation which as a result, affects their job performance. Poor motivation of employee resulting in poor performance of tasks assigned to them is one of the major problems confronting organizations in Nigeria, particularly library personnel of Nigerian Universities (Akor, 2010). It is on the basis of this that the research is set to find out the perceived effect of motivational strategies on the job performance of library personnel of universities in Benue State, Nigeria.

\section{Objectives of the study}

The main objective of the study was to investigate the perceived effect of promotion of staff and conducive work environment on the job performance of library personnel of universities in Benue State, Nigeria. Specifically, the study sought to:

i. determine the perceived effect of timely promotion on the job performance of library personnel of universities in Benue State.

ii. find out the perceived effect of good work environment on the job performance of library personnel of universities in Benue State.

Research questions The following research questions were answered in the study:

1. What is the perceived effect of timely promotion on the job performance of library personnel of universities in Benue State.

2. What is the perceived effect of good work environment on the job performance of library personnel of universities in Benue State, Nigeria.

\section{Hypotheses}

The following null hypotheses were tested at 0.05 level of significance:

Ho1: There is no significant difference between the mean ratings of responses of library personnel on the perceived effect of timely promotion on the job performance 
Margaret Mngusnur Ubagu, Uganneya Solomon Achia and Joseph Ahemba Gbuushi: Perceived effect of motivational strategies of promotion and work environment on the job performance of library personnel of universities in Benue State, Nigeria

of library personnel of universities in Benue State

Ho2: There is no significant difference between the mean ratings of responses of library personnel on the perceived effects of conducive work environment on the job performance of library personnel of universities in Benue State.

\section{Literature review}

Stueart and Moran (2007) regarded motivation at work as the sum of processes that influence the arousal, direction, and maintenance of behaviors relevant to work setting. Motivation strategies play an important role to increase employee's performance and also increase the productivity of an organization (Azar \& Shafighi, 2013), Tella, Ayeni and Popoola (2007) posited that motivational factors such as good pay, promotion, bonuses, job security and training opportunities have significant relationship to job performance. According to the authors, motivation is the key to job performance. Therefore, where motivation is lacking, low job performance is inevitable.

According to Adelabu (2008), low wages when compared with other professionals, low status in the society, lack of teachers' promotion, lack of career advancement opportunities, high teacher student ratio, poor work environment, inadequate fringe benefits, and irregular payment of teachers' salaries among others are the key reasons for low performance of teachers. Ngima and Kyongo (2013) saw motivation as goal directed behavior. People are motivated when they expect that a course of action is likely to lead to the attainment of a set goal, a valued reward one that satisfies their need. Kachalla, (2014) was of the opinion that motivation is a psychological process through which unsatisfied wants or needs lead to drives that are aimed at goals or incentives. The three basic elements in the process are needs, drives and goal-attainment. Robins,
Odendaal and Roudt (2009) remarked that motivation is a process in which people choose between alternative forms of behaviour in order to achieve personal goals. Badubi, (2017)also stressed that motivation affect job performance. The author remarks that "this encourages workers to want to retain their jobs." Ngima and Kyongo (2013), revealed that the link between motivation and performance in the workplace is a positive one; that is, the more motivated an employee is, the better will be his or her performance. Motivation has very strong influence on staff output, this presupposes why Upev,

Chorun and Idachaba (2015) suggested that it should not be limited to staff being paid regularly and promptly but in proportion to the volume of services rendered. Indeed, employee need good working environment, housing, medical allowance, transportation, regular promotion and training opportunities. Thus we advocate constant employee training and development. Similarly, Souza and Beuren (2018) observed that job brings satisfaction when it offers adequate mental challenge by offering opportunity to use skills, creativity, variety and some measure of autonomy in task performance. Job performance has to do with the degree of accomplishment of the work activities carried out by the worker towards the achievement of organizational goals (Ubagu, 2018).

Iqbal, Nabi, Muneer and Anuar (2013) stated that employees will put in their best in performing their jobs if they are motivated. Afful-Broni (2012), stated that individual performance is generally determined by three factors; namely, ability- the capability to do the job; work environment-the tools, materials and information needed to do the job; and motivation-the desire to do the job. The working definition of job performance therefore is the degree of accomplishment of the work activities carried out by the worker towards the achievement of 
Margaret Mngusnur Ubagu, Uganneya Solomon Achia and Joseph Ahemba Gbuushi: Perceived effect of motivational strategies of promotion and work environment on the job performance of library personnel of universities in Benue State, Nigeria

organizational goals as determined by the ability or capability to do the job, work environment including the tools, materials and information needed to do the job and motivation or the desire to do the job.

Robins, Odendaal and Roudt (2009) maintain that promotions provide opportunities for personal growth, increased responsibility, and increased social status. Souza and Beuren (2018)concluded that job satisfaction is the result of promotion opportunities in the organization. There are other researchers who discovered that there is positive relationship between promotion practices and perceived performance of employees. The findings of Ajie and Omotunde (2015) corroborated other researchers that many people experience satisfaction when they believe that their future prospects are good. This may translate into opportunities for advancement and growth in their current workplace, or enhance the chance of finding alternative employment. They maintained that if people feel they have limited opportunities for career advancement, their job satisfaction may decrease and if organizations want to accelerate performance of employees in the organization, fair promotional opportunities should be given to employees. According to Ugwuanyi (2012), the job performance of library personnel could be enhanced by encouraging them to strive, achieve or progress on their job. Management can do this by appreciating and instantly rewarding their good performances. In this case, library personnel who are due for promotion should not in any way be stagnated while those with exceptional performances may be recommended for accelerated promotion. Conducive work environment could be seen as the physical, social, psychological and technological conditions that are found in the work places that impart the job performance of librarians. This impact could be directly or indirectly, and environment could be internal or external. Environmental factors include social interaction, power supply, physical facilities, lighting level and motivation (Amusa, IyoroandOlabisi, 2013). The work place or environment can impede or enhance the productivity of librarians whose jobs require comfortable, conducive, and congenial environments. Kampert (2008) averred that employers who pay attention to all the details that affect the welfare of their workers, including their work environment are likely to retain the best people, save cost, and improve the productivity of their workers. Furthermore Sakir and Fajonyomi(2007) identified clean environment as part of the incentive packages that can be given to workers.

Ndagana(2007) noted the indispensability of a fine ecology to the output of workers. The author believes that the work place is one of the major focuses of evaluation of self. As a result, the working environment is likely to dampen employee's moral, and as a consequence, contributes less to the total organizational output. Iyoro (2005) on his part notes that investigations have demonstrated that, when workers are given the necessary motivation they require, they display maximum willingness in the discharge of their duties. In the same vain good ventilation in university libraries, according to Oyedum and Nwalo (2012), is a vital factor. The author believes that there is a strong link between good ventilation and students' use of library and librarians in providing their services. The author is also of the view that environmental survey should be carried out to ensure that there is always good air circulation around the reading areas which is necessary for adequate reading, learning and rendering of efficient services. Edwards and Fisher (2002) while commenting on library environment stated that there should be a balance between naturally ventilated libraries with fresh air and sunshine. The library's internal and external environment should also be aesthetically inviting. Also 
Margaret Mngusnur Ubagu, Uganneya Solomon Achia and Joseph Ahemba Gbuushi: Perceived effect of motivational strategies of promotion and work environment on the job performance of library

personnel of universities in Benue State, Nigeria

Amusa, Iyoro and Olabisi (2013) recommended that libraries should be attractive in its physical beauty and general ambience as this could attract more users.

Ajie and Omotunde (2015) found that work environment was an important determinant of job satisfaction and performance of employees. Working condition was also found to be a better determinant of job satisfaction and performance by the researchers. Ajie and Omotunde (2015) observed that working conditions had a moderate impact on the employee's job satisfaction and performance. According to them, if working conditions is good, for instance, clean and attractive surroundings, employees will find it easier to carry out their jobs. On the other hand, if the working condition is poor like hot and noisy surroundings, employees will find it difficult to get their work done and thereby experience dissatisfaction.

\section{Methods}

Survey research design was adopted for the study and a self-structured questionnaire was used for data collection. Population of 223 library personnel was used as sample. The researchers administered the questionnaires on face-to-face basis with the guidance of research assistant that helped to identify the library personnel. The data collected were analyzed using descriptive statistics(mean and standard deviation) to answer the research questions while inferential statistics of one way Analysis of Variance (ANOVA) was used to test the null hypotheses at 0.05 level of significance.

\section{Results and discussions}

This section deals with the presentation and analysis of data obtained from the respondents. In line with the research questions and objectives, data obtained are presented in this section.
Research question one: What is the perceived effectof timely promotion on the job performance of university library personnelin Benue State?

The data in Table 1 are used to answer this question.

The result in Table 1 reveal that item 1 has a mean of 3.47 and SD of .78, item 2 has a mean of 3.50 and SD of .71, item 3 has a mean of 3.39 and SD of .83, item 4 has a mean of 3.53 and SD of .70 and item 5 has a mean of 3.53 and SD of .70. With a Grand mean of 3.49 and SD of .48. This indicated that the respondents strongly agreed that timely promotion has effect on job performance of university library personnel in Benue State.

Research question two: What is the perceived effect of good work environment on the job performance of university library personnel in Benue State?

The data in Table 2 are used to answer this question. The result in Table 2 reveal that item 6 has a mean of 3.35 and SD of .88, item 7 has a mean of 3.30 and SD of .96, item 8 has a mean of 2.29 and SD of 1.20 , item 9 has a mean of 2.38 and SD of 1.24 , item 10 has a mean of 3.27 and SD of .95 , item 11 has a mean of 3.39 and SD of .90 , item 12 has a mean of 3.30 and SD of 1.10 and item 13 has a mean of 2.97 and SD of 1.29 with a grand mean of 3.03 and SD of .57 , this indicated that the respondents agreed that work environment has effects on the job performance of university library personnel in Benue State.

The formulated hypotheses for the study were tested at 0.05 level of significance.

Ho1: There is no significant difference between the mean ratings of responses of library personnel on perceived effects of promotion on the job performance of 
Margaret Mngusnur Ubagu, Uganneya Solomon Achia and Joseph Ahemba Gbuushi: Perceived effect of motivational strategies of promotion and work environment on the job performance of library personnel of universities in Benue State, Nigeria

library personnel of universities in Benue State.

The data used to test this hypothesis are presented in Tables 3a-b.

From Table 3a, it can be seen that the statistics for perceived effect of promotion on job performance was variously presented. From Benue State University, it was found that 78 library respondents had perceived mean effect on promotion to be 3.49 with standard deviation of $0.47,121$ library respondents in UAM had mean rating of 3.49 with standard deviation of 0.49 while that of 24 respondents from university of Mkar had 3.45 with standard deviation of 0.49 .

Check for the noted difference, as the results were not identical, ANOVA is to ascertain whether the noted differences are significant. The ANOVA is presented in table $3 b$. From Table $3 b$, it can be seen that the ANOVA results gave: $\mathrm{F}=0.08, \mathrm{df}=2$ and sig. $=0.92=$ p. Since $p$ is greater than 0.05 the difference noted is not significant. So the hypothesis which stated that there is no significant difference between the mean ratings of responses of library personnel on perceived effects of promotion on the job performance of library personnel of universities in Benue State is accepted.

Ho2: There is no significant difference between the mean ratings of responses of library personnel on perceived effects of good work environment on the job performance of library personnel of universities in Benue State.

The data used to test this hypothesis are presented in Tables $4 a-b$.

From Table 4a, it can be seen that the statistics for perceived effectof good work environment on the job performance of library personnel of universities in Benue Statewas variously presented. From Benue State University, it was found that 78 library respondents had perceived mean effect of good work environment on the job performance to be 3.28 with standard deviation of $0.51,121$ library respondents in UAM had mean rating of 2.98 with standard deviation of 0.55 while that of 24 respondents from University of Mkar had 2.48 with standard deviation of 0.43 . Check for the noted difference, as the results were not identical, ANOVA is used to ascertain whether the noted differences are significant. The ANOVA is presented in table $4 \mathrm{~b}$. From Table $4 \mathrm{~b}$, it can be seen that the ANOVA results gave: $\mathrm{F}=22.62, \mathrm{df}=2$ and sig. $=0.00=$ p. Since $p$ is less than 0.05 the difference noted is significant. So the hypothesis which stated that there is no significant difference between the mean ratings of responses of library personnel on perceived effects of work environment on the job performance of library personnel of universities in Benue State is rejected. 
Margaret Mngusnur Ubagu, Uganneya Solomon Achia and Joseph Ahemba Gbuushi: Perceived effect of motivational strategies of promotion and work environment on the job performance of library personnel of universities in Benue State, Nigeria

Table 1: Perceived mean ratings of the effects of timely promotion on the job performance of university library personnel in Benue State

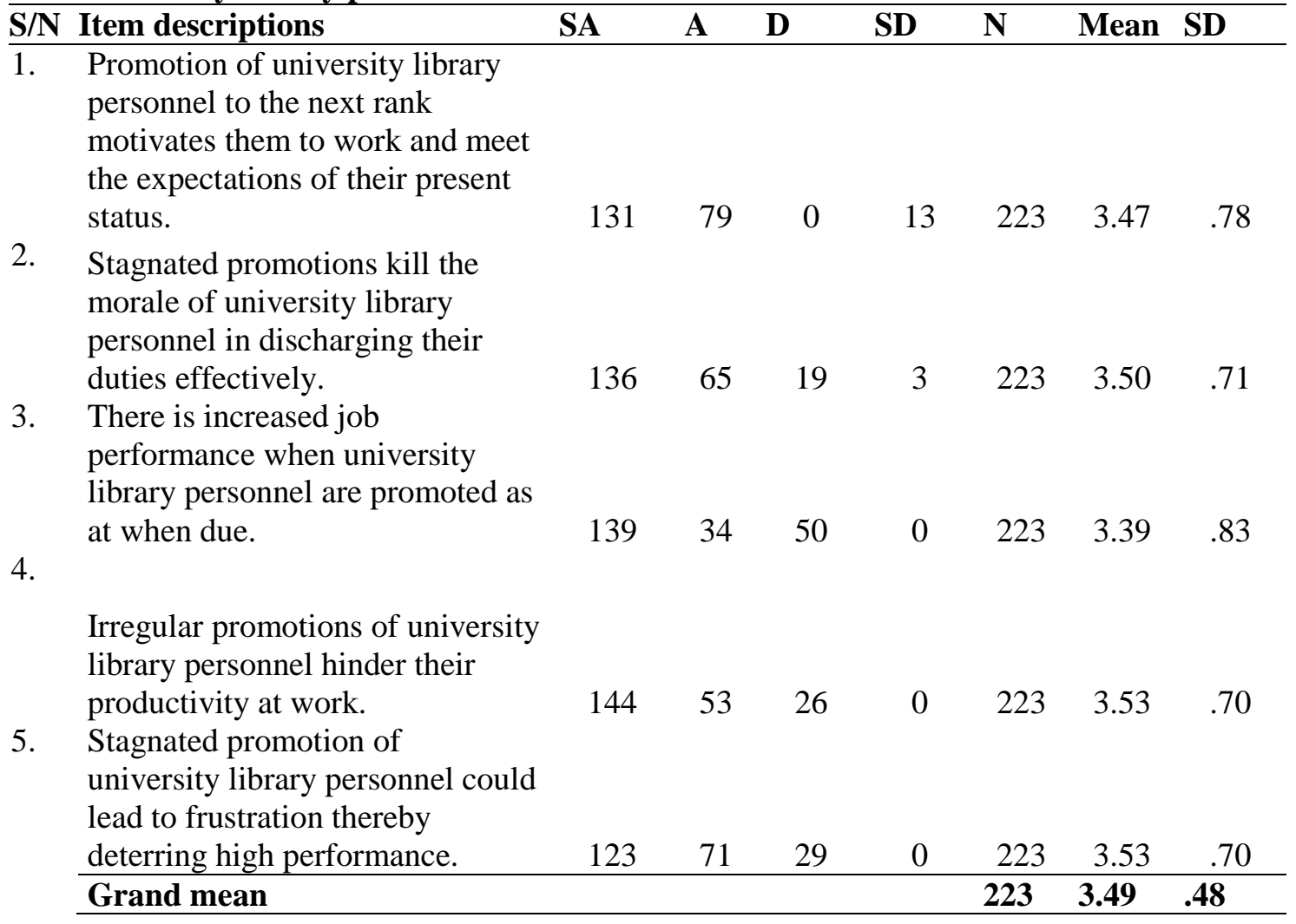

Table 2: Perceived mean ratings of the effects of work environment on the job performance of university library personnel in Benue State

\begin{tabular}{|c|c|c|c|c|c|c|c|c|}
\hline \multirow[t]{2}{*}{$\mathbf{S} / \mathbf{N}$} & Item Descriptions & $\mathbf{S A}$ & $\mathbf{A}$ & $\mathbf{D}$ & SD & $\mathbf{N}$ & Mean & SD \\
\hline & $\begin{array}{l}\text { Job performance of university library personnel is enhanced } \\
\text { when there are well equipped information and communication } \\
\text { technology gadgets such as computers. }\end{array}$ & 139 & 24 & 60 & 0 & 223 & 3.35 & .88 \\
\hline 7 & Inadequate library facilities such as internet connectivity & & & & & & & \\
\hline & hinder high quality job o & 137 & 27 & 49 & 10 & 223 & 3.30 & .96 \\
\hline 8 & $\begin{array}{l}\text { Poor lighting and high temperatures around library } \\
\text { environment distort job performance among university library } \\
\text { personnel. }\end{array}$ & 61 & 19 & 66 & 77 & 223 & 2.29 & 1.20 \\
\hline 9 & $\begin{array}{l}\text { Location of libraries in accessible and secured environment } \\
\text { could encourage high job performance of university library } \\
\text { personnel. }\end{array}$ & 68 & 25 & 54 & 76 & 223 & 2.38 & 1.24 \\
\hline 10 & $\begin{array}{l}\text { Noisy library environment is unconducive for effective job } \\
\text { performance of university library personnel. }\end{array}$ & 125 & 47 & 37 & 14 & 223 & 3.27 & .95 \\
\hline 11 & $\begin{array}{l}\text { Provision of spacious library environment could yield better } \\
\text { service delivery. }\end{array}$ & 145 & 26 & 46 & 6 & 223 & 3.39 & .90 \\
\hline & $\begin{array}{l}\text { Provision of well ventilated library environment could } \\
\text { enhance better service delivery. }\end{array}$ & 151 & 12 & 34 & 26 & 223 & 3.30 & 1.10 \\
\hline 13 & $\begin{array}{l}\text { Installation of functional air conditions and noiseless fans } \\
\text { could create conducive work environment for high job } \\
\text { performance. }\end{array}$ & 120 & 40 & 0 & 63 & 223 & 2.97 & .29. \\
\hline & Grand mean & & & & & 223 & 3.03 & .57 \\
\hline
\end{tabular}


Margaret Mngusnur Ubagu, Uganneya Solomon Achia and Joseph Ahemba Gbuushi: Perceived effect of motivational strategies of promotion and work environment on the job performance of library

personnel of universities in Benue State, Nigeria

Table 3a: Statistics of university library on perceived effect of promotion on the job performance

\begin{tabular}{lllll}
\hline & $\mathbf{N}$ & Mean & Std. Deviation & Std. Error \\
\hline BSU & 78 & 3.49 & .47 & .05 \\
UAM & 121 & 3.49 & .49 & .04 \\
Uni. & 24 & 3.45 & .49 & .10 \\
Mkar & & $\mathbf{3 . 4 9}$ & $\mathbf{. 4 8}$ & $\mathbf{. 0 3}$ \\
Total & $\mathbf{2 2 3}$ & & & \\
\hline
\end{tabular}

Table 3b: ANOVA for Perceived Effect of Promotion on Job Performance of University Library Personnel

\begin{tabular}{lccccc}
\hline & Sum of Squares & df & Mean Square & F & Sig. \\
\hline Between Groups & .04 & 2 & .02 & .08 & .92 \\
Within Groups & 50.79 & 22 & .23 & & \\
Total & 50.83 & 22 & & & \\
\hline
\end{tabular}

Table 4a: Statistics of University Library Perceived Effect ofWork Environment on Job Performance

\begin{tabular}{lllll}
\hline & $\mathbf{N}$ & Mean & Std. Deviation & Std. Error \\
\hline BSU & 78 & 3.28 & .51 & .06 \\
UAM & 121 & 2.98 & .55 & .05 \\
Uni. & 24 & 2.48 & .43 & .09 \\
Mkar & $\mathbf{2 2 3}$ & $\mathbf{3 . 0 3}$ & $\mathbf{. 5 7}$ & $\mathbf{. 0 4}$ \\
Total & $\mathbf{2 2 3}$ & & \\
\hline
\end{tabular}

Table 4b: ANOVA for perceived effect of good work environment on job performance of university library personnel

\begin{tabular}{lccccc}
\hline & Sum of Squares & Df & Mean Square & F & Sig. \\
\hline Between Groups & 12.397 & 2 & 6.20 & 22.62 & .00 \\
Within Groups & 60.289 & 220 & .27 & & \\
Total & 72.687 & 222 & & & \\
\hline
\end{tabular}

\section{Discussion}

The finding of research question one revealed that there was no significant difference between the mean ratings of responses of library personnel on perceived effects of promotion on the job performance of library personnel of universities in Benue State. Responses on timely promotion of staff however show that timely promotion of staff has positive effect on the job performance of university library personnel in Benue State. The findings therefore imply that university library personnel had similar responses regarding the perceived effect of timely promotion of staff on the job performance of library personnel of universities in the state. This finding was also in line with Ugwuanyi (2012) who ascertained that the job performance of library personnel could be enhanced by encouraging them to strive, achieve or progress on their job. Ugwuanyi (2012) further stated that library personnel who are due for promotion should not in any way be stagnated while those with exceptional performances may be recommended for accelerated promotion. This finding was in disagreement with that of Adelabu (2008) who studied teacher motivation crises in Nigeria and found that teachers are poorly motivated and are dissatisfied with their living and working conditions partly due to lack of teachers' promotion and lack of career advancement opportunities. There was no significant difference between the mean ratings of responses on perceived effects of promotion on the job performance of library personnel 
Margaret Mngusnur Ubagu, Uganneya Solomon Achia and Joseph Ahemba Gbuushi: Perceived effect of motivational strategies of promotion and work environment on the job performance of library personnel of universities in Benue State, Nigeria

of universities in Benue State. This could be attributed to the fact that most of the library personnel were satisfied with the way promotion was given to them (got their promotion when it was due) as well as statistical with their progress on the job.

The finding of research question two revealed that there was a significant difference between the mean ratings of responses of library personnel on perceived effects of work environment on the job performance of library personnel of universities in Benue State. Respondents however, indicated that work environment had positive effect on the job performance of university library personnel in Benue State. The findings therefore implied that university library personnel had different responses regarding the perceived effect of work environment on the job performance of library personnel of universities in the State. The finding is in agreement with that of Adelabu (2008), who studied teacher motivation crises in Nigeria and found that teachers are poorly motivated and are dissatisfied with their living and working conditions partly due to poor work environment. The finding is also in line with Ndagana (2007) who noted that the working environment dampen employee's moral, and as a consequence, contributes less to the total organizational output. Ajie and Omotunde (2015) were of the view that working conditions had a moderate impact on the employee's job satisfaction and performance. According to them if working conditions are good, for instance - clean and attractive surroundings, employees will find it easier to carry out their jobs. On the other hand, if the working conditions are poor like hot and noisy surroundings, employees will find it difficult to get their work done and thereby experience dissatisfaction.

There was a significant difference between the mean ratings of responses on perceived effects of work environment on the job performance of library personnel of universities in Benue State. This could be attributed to different environmental factors like social interaction between junior and senior library personnel, physical structures (building), and location of the library as well as facilities available at the work environment of the various university libraries.

\section{Conclusion}

Based on the study findings, it has been concluded that motivation has positive effect on the job performance of library personnel of universities in Benue State. Hence, the indices of motivation such as staff timely promotion and work environment had significant difference on library personnel in the three universities where the study was conducted. Based on the findings of the study, the study recommend that work environment of the university libraries in Benue State should be made conducive by the provision of adequately equipped and well ventilated space, ICT gadgets such as computers, internet connectivity, for enhanced job performance.

\section{References}

Adelabu, M. A. (2008). Teachers' motivation crisis in Nigeria. International Journal of Humanities and social Science Invention, 2(51), 35-41.

- Afful-Broni, A. (2012). Relationship between motivation and job performance of the University of Mines and Technology, Tarkwa, Ghana: Leadership lessons. Creative Education, 3(03), 309-314. DOI: 10 .4236/ce.2012.33049. Retrieved from: https://www.researchgate.net /publication/276489564_Relationshi p_between_Motivation_and_Job_Pe rformance_at_the_University_of_M ines_and_Technology_Tarkwa_Gha na_Leadership_Lessons.

Ajie, I. A., \& Omotunde, O. I. (2015). Job satisfaction and organizational 
Margaret Mngusnur Ubagu, Uganneya Solomon Achia and Joseph Ahemba Gbuushi: Perceived effect of motivational strategies of promotion and work environment on the job performance of library personnel of universities in Benue State, Nigeria

commitment among library personnel in selected libraries in Ogun State, Nigeria. Information and Knowledge Management, 5(10), $22-24$.

Akor, P. U. (2010). Motivation as correlate to job performance of professional librarians in the university libraries in Makurdi, Benue State. Unizik Journal of Research in Library and Information Science, 2(1), 54-64.

Amusa, O. I., Iyoro, A. O., \& Olabisi, A. F. (2013). Work environments and job performance of librarians in the public universities in South-West Nigeria. International Journal of Library and Information Science, 2(4), 47-67.

Azar, M., \& Shafighi, A. (2013). The effect of work motivation on employees' job performance. International Journal of Academic Research in Business and Social Sciences, 3(9), 22-26.

Badubi, R. M. (2017). Theories of motivation and their application in organizations: A risk analysis. International Journal of Management Science and Business Administration, 3(3), 44-51.

Edwards, B., \& Fisher, B. (2002). Libraries and learning resource centres. Oxford: Architectural Press.

Iqbal, S. M. J., Nabi, A. A., Muneer, S. \& Anuar, M. A. (2013). Impact of training on expectation of employee and employer: a comparative study. Information Management and Business Review, 5, 601-607.

Iyoro, A. O. (2005). Influence of self concept, job motivation and satisfaction on work performance of university library personnel in South-West , Nigeria. Ago-Iwoye J. Socal Behaviouser Science, 1(2), 96-110.

Kachalla, B. (2014). Review of the role of motivation on employee performance. Mediterranean
Journal of Social Sciences, 5(17), 39-48. Doi:10.5901/mjss.2014.v5 n17p39.

Kampert, P. (2008). Good work environment improves satisfaction, and productivity. Tribune June 8

Katamba, A. S.,and Abdulsalam, A. S. (2014). An assessment of the levels of job motivation and satisfaction as predictors of job performance of library personnel in Nigerian universities. Journal of Balkan Libraries Union, 2(2), 26-33.

Kendra, C. (2019). The incentive theory of motivation: are actions ' $\mathrm{B}$ ' a desire for rewards? Retrieved from https://www.verywellmind.com/theincentive-theory-of-motivation2795382

Ndagana, J.M. (2007). Behavioural pattern of non-academic staff of federal universities in Nigeria to job dissatisfaction.Educational Forum, 10(1):1677-1184.

Ngima, W. M., and Kyongo, J. (2013). Contribution of Motivational Management to Employee Performance.International Journal of Humanities and Social Science,3(14), 219-239.

Robins, S. P., Judge, T. A., \& Vohra, N. (2013). Organizational behaviour. $\left(15^{\text {th }}\right.$ ed) USA: Peason Education.

Sakir, A., and Fajonyomi, A. A. (2007). Career growth and financial benefit as factors motivating grade II teachers in Borno State to return to further training. Educational Forum, 10(1), 21-25.

Souza, G. E. \& Beuren, I. M. (2018). Impact of an enabling performance measurement system on task performance and job satisfaction. RevistaContabilidade \& Finanças, 29(77), 194-212. DOI: https://dx.doi.org/10.1590/1808-05 $7 \times 201805850$.

Stueart, R. D. \& Moran, B. B. (2007). The human resource function in the 
Margaret Mngusnur Ubagu, Uganneya Solomon Achia and Joseph Ahemba Gbuushi: Perceived effect of motivational strategies of promotion and work environment on the job performance of library personnel of universities in Benue State, Nigeria

library. Library and information center management. London: Libraries Unlimited,

Tella, A., Ayeni, C. O. \& Popoola, S. O. (2009). Work motivation, job satisfaction and organizational commitment of library personnel in academic and research libraries in Oyo State. Library Philosophy and Practice, 7(4), 1-16. Retrieved from https://digitalcommons.unl.edu/cgi/ viewcontent.cgi? article $=1118 \&$ cont ext=libphilprac.

Ubagu, M. M. (2018). Perceived effect of motivation on the job performance of library personnel of universities in Benue State. Unpublished thesis submitted to the Department of Educational Foundations and General Studies, Federal University of Agriculture, Makurdi in partial fulfillment of the requirements for the award of masters in library and information science.

Uganneya S. A. \& Agoh, A. (2013). Libraries for higher education students. Makurdi. Glory Ikani Printers.

Ugwuanyi, R. N. C. (2013). Motivation in academic libraries: an imperative for efficient information delivery. African Journal of Information and Knowledge Management, 1(1), 33 67.

Upev, M. T., Chorun, M. T. \& Idachaba, J. A. (2015). The effects of motivation on staff productivity/performance at the Francis Sulemanuu Idachaba Library, University Of Agriculture, Makurdi-Nigeria. IOSR Journal of Research \&Method in Education (IOSR-JRME), 5(2), 1-7 